\title{
AN ELECTROPHORETIC STUDY OF SERUM PROTEINS IN THYROIDITIS ${ }^{1}$
}

\author{
BY NORMAN WEISSMAN ${ }^{2}$ AND MARTIN PERLMUTTER \\ (From the Medical Services, Maimonides Hospital, Brooklyn, and the Department of Internal \\ Medicine, State University of New York College of Medicine at New York, \\ Brooklyn, N. Y.)
}

(Submitted for publication December 26, 1956; accepted February 14, 1957)

The clinical picture of acute thyroiditis ${ }^{8}$ may be so classical that the diagnosis is obvious. However, very often, the symptomatology may be obscure. Several investigators have sought for a laboratory test, specific for the disease, to complement the clinical observations. In 1949, Werner, Quimby, and Schmidt (1) reported that six patients with thyroiditis had exceedingly low thyroidal uptakes of radioactive iodine. Hamilton, Kirkendall, and Barker (2), in addition to confirming this isotopic finding, also reported that the level of serum protein bound iodine (PBI) was either high normal or abnormally high. These two laboratory findings have helped to diagnose many obscure cases of thyroiditis. Patients who have ingested or received an injection of iodide compounds, may also show low thyroidal uptake of I-131 and an elevation of the serum PBI. Therefore, it would be helpful to have a test, not dependent on iodine metabolism, confirmatory of the disease.

One year ago, we studied a patient whose fever of unknown origin proved to be due to thyroiditis. In addition to the above mentioned abnormalities in iodine metabolism, we noted a markedly abnormal electrophoretic serum protein pattern. This abnormality consisted of an increase in alpha-1, alpha-2, and gamma globulin. Since this chance observation, we have examined the electrophoretic patterns of the sera of seven other patients who had subacute thyroiditis. All eight electrophoretic patterns were similar. After these data

\footnotetext{
1 This investigation was supported in part by a grant from the American Cancer Society and by Research Grant G3904C from the National Institutes of Health, Public Health Service.

2 Present address : University of Utah College of Medicine, Department of Pathology, Salt Lake City 15, Utah.

3 In this paper we will use the following terms interchangeably to signify the same disease: acute thyroiditis, subacute thyroiditis, and thyroiditis.
}

had been assembled, we noted the report of Stemmerman (3) that his four patients with thyroiditis had abnormally high alpha-2 fractions as determined by paper electrophoresis.

It is the purpose of this report to present the electrophoretic patterns of the serum proteins observed in thyroiditis, and to discuss the value of such observations with regard to the diagnosis of this disease. We will also relate the present findings to previous reports of the electrophoretic studies made on pathological sera and thyroid preparations. Finally, some observations will be made on the use of free versus paper electrophoresis in clinical diagnosis.

\section{METHODS}

Blood was drawn from patients in the fasting state. The separated serum was diluted with three volumes of diethylbarbiturate buffer ( $\mathrm{pH} 8.6$, ionic strength 0.1 ), dialyzed in the cold against the same buffer, and electrophoresed in a Perkin-Elmer model No. 38 Tiselius apparatus. Planimetry of the diagrams established the relative per cent composition of the sera.

The serum protein bound iodine was determined by the dry ashing technique described by Barker, Humphrey, and Soley (4). The range of serum PBI of normal subjects in our laboratory is from 3 to 7 gamma per $100 \mathrm{ml}$. The uptake of radioactive iodine by the thyroid was measured 24 hours after the ingestion of approximately 5 microcuries of radioactive iodine (I-131). A scintillation counter ${ }^{4}$ was placed 20 centimeters from the neck. Counts were taken of the entire head and neck area. The background counts from the head and neck area, excluding the thyroid gland, were then recorded by shielding the thyroid area with a one-inch-thick lead block. The difference between these two counts was considered to be the count from the radioactive iodine within the thyroid gland. Counts were similarly recorded from the contents of a vial containing an aliquot of the ingested dose of I-131 in $10 \mathrm{ml}$. of water. Thus, the percentage of the ingested dose was easily calculated (5). The range of thyroidal uptakes in normal subjects in our laboratory is between 15 and 50 per cent.

\footnotetext{
4 Model DS-1 Scintillation Counter, Nuclear Instruments and Chemicals Corp., Chicago, Ill.
} 


\section{RESULTS}

Table I contains the data derived from the electrophoretic diagrams. In all eight cases, albumin was lowered from the normal range of 55 to 60 per cent to between 35 to 45 per cent, and gamma globulin was elevated. In seven of the eight cases, there also were marked rises in alpha-1 and alpha-2 globulins. It can be seen that either alpha-1 or alpha-2 globulin may be higher, and that the two may shift their relative concentrations during the course of the patient's disease (Table I, Case 1). In Case 7, alpha-1 globulin, and in Case 8, alpha-2 were not elevated. Case 1 had a quite elevated gamma globulin which decreased over a two-week interval. Slight increases from the normal mean for beta globulin were noted in most of these cases. Cases 1 and 4 were followed for some time after the diagnosis of thyroiditis was established. As the alpha globulins decreased, albumin rose in both, there was an increase in beta globulin in Case 1, while Case 4 had a normal pattern three months later.

Although these eight cases form a small series, the average mean increases from the normal for alpha-1, alpha-2, and gamma globulin are about equal, with a similar standard deviation (Table I).

The thyroidal uptake of I-131 in each of these cases was less than 3 per cent (Table II). Nine of ten other cases of this disease, previously studied in our laboratory, similarly showed a markedly decreased ability to concentrate iodide. The level of serum PBI was above normal in three of the six patients studied and high normal in three others.

\section{DISCUSSION}

\section{Significance of electrophoretic data}

Our data show that in thyroiditis there occur a consistent elevation of serum alpha-1, alpha-2, and gamma globulins, a less marked rise in beta globulin, and a moderate decrease in albumin. Such changes are not specific for any single disease. Similar findings have been reported for Hodgkin's disease, protein deficiency states, febrile conditions, rheumatoid arthritis, lupus erythematosis disseminata, etc. (6-9). Shedlovsky and Scudder concluded from their electrophoretic studies that: "An increase in alpha globulin levels appears to take place, as well as an increase in sedimentation rates, when there is present any considerable inflammation or tissue destruction, irrespective of its cause" (8). They also noted that the highest alpha globulin values corresponded to febrile disease states. Chow demonstrated a definite negative correlation coefficient between the percentages of albumin and total alpha globulins in the various deficiency states studied by him (7). He has also discussed the question of attributing diagnostic specificity to alterations in protein patterns. Petermann, Karnofsky, and Hogness (6) showed that the alpha-1, alpha-2, and gamma globulins in Hodgkin's disease were often elevated to the same extent as we have reported for thyroiditis in this paper. These authors stated : "The electrophoretic

TABLE I

Distribution of serum proteins in thyroiditis

\begin{tabular}{|c|c|c|c|c|c|c|c|c|c|c|c|}
\hline \multirow[b]{2}{*}{ Case } & \multirow[b]{2}{*}{ Sex } & \multirow[b]{2}{*}{ Age } & \multirow[b]{2}{*}{ Date } & \multicolumn{5}{|c|}{$\%$ Protein in serum } & \multicolumn{3}{|c|}{$\%$ Deviation from normal } \\
\hline & & & & Alb. & Alpha-1 & Alpha-2 & Beta & Gamma & Alpha-1 & Alpha-2 & Gamma \\
\hline \multicolumn{4}{|c|}{ Normal* } & 59 & 5.6 & 9.3 & 14.3 & 12 & & & \\
\hline $\begin{array}{l}1 \\
1 \\
2 \\
3 \\
4 \\
5 \\
6 \\
7 \\
8\end{array}$ & $\begin{array}{l}F \\
F \\
M \\
F \\
M \\
M \\
F \\
M \\
F\end{array}$ & $\begin{array}{l}68 \\
68 \\
49 \\
40 \\
40 \\
38 \\
45 \\
48 \\
26\end{array}$ & $\begin{array}{c}10 / 23 / 55 \\
11 / 1 / 55 \\
10 / 31 / 55 \\
1 / 11 / 56 \\
2 / 15 / 56 \\
4 / 20 / 56 \\
4 / 15 / 56 \\
5 / 14 / 56 \\
11 / 30 / 56\end{array}$ & $\begin{array}{l}35.4 \\
40.3 \\
43.5 \\
37 \\
42 \\
40.6 \\
42.6 \\
47 \\
43.6\end{array}$ & $\begin{array}{r}8.04 \\
8.6 \\
8.8 \\
11.5 \\
7.5 \\
10.2 \\
8.8 \\
5.8 \\
11.0\end{array}$ & $\begin{array}{l}15 \\
13.3 \\
14.1 \\
20.5 \\
17 \\
15.7 \\
12.2 \\
12.9 \\
10.2\end{array}$ & $\begin{array}{l}16 \\
14.3 \\
16.5 \\
14.5 \\
17.8 \\
16.1 \\
17.7 \\
17.3 \\
15.7\end{array}$ & $\begin{array}{l}25.4 \\
23.6 \\
17 \\
16.5 \\
15.8 \\
17.3 \\
18.5 \\
17 \\
19.3\end{array}$ & $\begin{array}{r}+44 \\
+54 \\
+58 \\
+106 \\
+34 \\
+83 \\
+58 \\
+\quad 4 \\
+96\end{array}$ & $\begin{array}{r}+62 \\
+44 \\
+52 \\
+121 \\
+83 \\
+69 \\
+32 \\
+39 \\
+10\end{array}$ & $\begin{array}{l}+111 \\
+96 \\
+41 \\
+37 \\
+31 \\
+43 \\
+53 \\
+41 \\
+61\end{array}$ \\
\hline \multicolumn{4}{|l|}{ Mean } & & & & & & +60 & +57 & +57 \\
\hline \multicolumn{4}{|c|}{ Standard deviation } & & & & & & \pm 30 & \pm 30 & \pm 26 \\
\hline
\end{tabular}

* Modified from Armstrong, S. H., et al. (Ref. 12). 
TABLE II

\begin{tabular}{ccc}
\hline Case & $\begin{array}{c}\text { Uptake of } \\
\text { III }^{\text {au }}\end{array}$ & $\begin{array}{c}\text { Serum } \\
\text { PBI }\end{array}$ \\
\hline 1 & $2^{*}$ & $7.8 \dagger$ \\
2 & 3 & \\
3 & 3 & 5.0 \\
4 & 0 & 15.0 \\
5 & 0 & 6.9 \\
6 & 1 & 5.9 \\
7 & 0 & 9.9 \\
8 & 2 & \\
\hline
\end{tabular}

* Per cent of ingested dose.

† Gamma per $100 \mathrm{ml}$. serum.

patterns seen in moderately advanced Hodgkin's disease are consistent with a chronic infectious disease." The bibliography given at the end of the present paper refers to other publications which make abundantly clear the non-specificity of change in the alpha, or gamma globulin content of blood. Skillern, Nelson, and Crile, using free electrophoresis, have studied six cases of thyroiditis. They found a decreased albumin in five of the six, a slightly increased gamma globulin in two, an increased alpha-1 and alpha-2 in one, and a slight elevation of beta globulin in one. They regard the protein changes as non-specific (10).

Stemmerman's apparently incomplete observations in patients with thyroiditis, based on paper electrophoresis, led him to propose a test which we believe is not valid. He did not report any change other than in alpha-2 globulin. Further, he buttresses the significance of his alpha- 2 finding by referring to the work of Shulman, Rose, and Witebsky (11). These authors report that crude hog thyroid gland extract was found, by paper electrophoresis, to migrate with a mobility slightly greater than that of hog alpha-2 globulin (1). Reference to this article shows that the mobilities on paper, used to characterize the hog extract, were calculated by extrapolation of data taken from free solution electrophoresis and by reference to albumin migration. The calculated mobility for the hog "thyroglobulin" is an approximation which probably cannot be extrapolated to human sera. In addition, it is well known that all electrophoretic mobilities of proteins are partially dependent on the relative concentration of the protein components in the solution under test (12). This is another reason why the calculations of Shulman, Rose, and Witebsky are of questionable value when applied to the migration of components in human sera, as was done by Stemmerman. This point is clearly demonstrated by Gordon, Gross, O'Connor, and Pitt-Rivers in their electrophoretic study of the nature of the circulating thyroid hormone-plasma protein complex (13). Thyroxine labelled with I-131 was shown to migrate with alpha-1 globulin when mixed with serum, although it did not move frum the starting boundary when electrophoresed by itself. These authors also compared free and paper electrophoresis of the same serum and showed the coincidence of the major I-131 activity with the alpha-1 region.

It is evident from the electrophoretic data $i_{2}$ the present paper and others cited (6-9) that the pattern found in the sera of patients suffering from thyroiditis is a reflection of a febrile process accompanied by some tissue inflammation and destruction. Perhaps a lack of sensitivity in the paper electrophoresis method used by Stemmerman obscured alpha-1 and gamma globulin changes. Since no quantitative data were given by this author, it is difficult to judge the point. Therefore, it would seem unwise to advocate that paper electrophoresis is a simple substitute for the earlier procedures used in the diagnosis of thyroiditis. A specific laboratory test for thyroiditis still remains to be found.

\section{SUMMARY AND CONCLUSIONS}

1. Eight cases of clinically diagnosed thyroiditis have been studied by free solution electrophoresis, radio-iodine uptake, and protein bound iodine determinations.

2. Abnormal serum protein patterns were found in all eight cases. The changes found were considered to be non-specific for the disease, and the result of a febrile process accompanied by some tissue inflammation and destruction. The use of paper electrophoresis as a diagnostic tool in thyroiditis has been evaluated. The claim that an elevated alpha- 2 globulin is uniquely characteristic of thyroiditis is not confirmed.

3. The radioactive iodine uptake measurements were significantly abnormal in all eight cases studied. 
4. The determination of serum protein bound iodine was less helpful in diagnosing the disease.

5. It is concluded that a specific diagnostic test for thyroiditis does not exist at present.

\section{ACKNOWLEDGMENTS}

We wish to thank Mrs. Leatrice Kaplan and Mr. Marvin Numeroff for technical assistance, and Dr. Stanley Slater for making available to us a case of thyroiditis.

\section{REFERENCES}

1. Werner, S. C., Quimby, E. H., and Schmidt, C., The use of tracer doses of radioactive iodine, $\mathrm{I}^{12}$, in the study of normal and disordered thyroid function in man. J. Clin. Endocrinol., 1949, 9, 342.

2. Hamilton, H. E., Kirkendall, W. M., and Barker, S. B., Radioactive iodine uptake of the thyroid and plasma protein bound iodine in subacute thyroiditis. J. Clin. Invest., 1950, 29, 819.

3. Stemmerman, G. N., Serum protein changes in subacute thyroiditis. J. A. M. A., 1956, 162, 31.

4. Barker, S. B., Humphrey, M. J., and Soley, M. H., The clinical determination of protein-bound iodine. J. Clin. Invest., 1951, 30, 55.

5. Perlmutter, M., Weisenfeld, S., Slater, S., and Wallace, E. Z., A study of the mechanism of the inhibition of the thyroid gland induced by ingestion of thyroid substance. J. Clin. Endocrinol. \& Metab., 1952, 12, 208.
6. Petermann, M. L., Karnofsky, D. A., and Hogness, K. R., Electrophoretic studies on the plasma proteins of patients with neoplastic disease. III. Lymphomas and leukemia. Cancer, 1948, 1, 109.

7. Chow, B. F., The correlation between the albumin and alpha globulin contents of plasma. J. Clin. Invest., 1947, 26, 883.

8. Shedlovsky, T., and Scudder, J., A comparison of erythrocyte sedimentation rates and electrophoretic patterns of normal and pathological human blood. J. Exper. Med., 1942, 75, 119.

9. Schoenbach, E. B., Weissman, N., and Armistead, E. B., The determination of sulfhydryl groups in serum. II. Protein alterations associated with disease. J. Clin. Invest., 1951, 30, 762.

10. Skillern, P. G., Nelson, H. E., and Crile, G., Jr., Some new observations on subacute thyroiditis. J. Clin. Endocrinol. \& Metab., 1956, 16, 1422.

11. Shulman, S., Rose, N. R., and Witebsky, E., Studies on organ specificity. III. Ultracentrifugal and electrophoretic examinations of thyroid extracts. J. Immunol., 1955, 75, 291.

12. Armstrong, S. H., Jr., Budka, M. J. E., and Morrison, K. C., Preparation and properties of serum and plasma proteins. XI. Quantitative interpretation of electrophoretic schlieren diagrams of normal human plasma proteins. J. Am. Chem. Soc., 1947, $69,416$.

13. Gordon, A. H., Gross, J., O'Connor, D., and PittRivers, R., Nature of the circulating thyroid hormone-plasma protein complex. Nature, 1952, 169, 19. 